Jan Mazur osppe

(D) https://orcid.org/0000-0002-0548-0205

Uniwersytet Papieski Jana Pawła II w Krakowie

\title{
Uwagi o tożsamości ideowej polskiego ruchu społecznego „Solidarność"
}

(di) https://doi.org/10.15633/9788374389839.03

\section{Czym jest tożsamość ideowa?}

Pytanie o tożsamość ideową polskiego ruchu społecznego, który kojarzony jest z ideą solidarności, można sprowadzić do kwestii jego identyfikacji w oparciu o charakterystyczne cechy. Chodzi rzecz jasna o ruch oparty na fenomenie solidarności, który w ostatnich dwóch dekadach xx wieku przyczynił się do upadku imperium sowieckiego i zapoczątkował przemiany społeczno-ustrojowe w Polsce, jak również w całym bloku państw Europy Środkowej i Wschodniej. Analiza fenomenu solidarności nie jest łatwa, gdyż kryje w sobie wiele powiązanych z sobą wątków treściowych. Nie sposób ich nie uwzględnić, podejmując kwestię tożsamości samego fenomenu oraz generowanego przez ów fenomen ruchu ideowego. Ruch ten jawi się wieloaspektowo. Jest głęboko osadzony w sprawach społecznych (socjalnych), gospodarczych, politycznych, a także może być postrzegany w kontekście religijnym, etycznym, kulturalnym, akademickim, prawniczym itp. We wszystkich tego rodzaju odniesieniach można mówić o tej samej solidarności, która łączy ludzi i w pewnym sensie identyfikuje, potwierdza ich tożsamość.

W naukach społecznych, a szczególnie w naukach socjologicznych na ogół wyróżnia się dwa rodzaje tożsamości: tożsamość osobistą (służy samookreśleniu się osoby z intencją odróżnienia się od innych ludzi, podkreśleniu swojej wyjątkowości, indywidualności, postrzeganiu siebie jako jednostki wewnętrznie spójnej, z własną historią) i tożsamość społeczną 
(grupową). Ten ostatni rodzaj tożsamości niejako włącza człowieka w społeczność, akcentuje jego przynależność, podobieństwo, poczucie bezpieczeństwa i akceptacji, jakie daje grupa społeczna, wspólnota. Tożsamość osoby zwykle jest zdeterminowana włączeniem w obszar własnej, indywidualnej tożsamości cech wspólnych dla członków społeczności, do której się przynależy. Badania zdają się potwierdzać, że w sytuacji istnienia więzi grupowej czy kontaktu międzygrupowego wzmacnia się tendencja do wysuwania się tożsamości społecznej (grupowej) na pierwszy plan. Przynależność do grupy służy budowaniu poczucia wspólnoty z nierzadko pojawiającą się tendencją do stawiania własnej grupy ponad innymi grupami ${ }^{1}$.

W sumie tożsamość społeczna stanowi jeden z ważniejszych rodzajów tożsamości jako takiej. Odwołując się do określenia przynależności do konkretnej grupy społecznej, jest jednocześnie odpowiedzią na pytanie: „kim jestem w stosunku do innych ludzi?” lub „kim jest moja grupa w stosunku do innych grup?”. Więcej, tożsamość społeczną można zdefiniować jako „element symbolicznego modelu świata, wyznaczający każdemu człowiekowi i każdej grupie miejsce w relacji do innych ludzi i grupy, w ramach uporządkowanego i posiadającego kulturowy wyraz uniwersum"2.

Szczególnym wyrazem tożsamości społecznej jest tożsamość ideowa. Można przyjąć założenie, że tożsamość ideową jako taką można definiować za pomocą celów politycznych, obejmując niejako wspólne wartości, tradycje i oczekiwania względem przyszłości. W tej perspektywie tożsamość ideową wprowadza w czyny, realizuje właśnie tożsamość polityczną ${ }^{3}$.

\section{Duch etyki solidarności Tischnera}

Wydaje się, iż w oparciu o sens, jaki kryje w sobie kategoria tożsamości ideowej, można głębiej wniknąć, bardziej zrozumieć to, czym była i czym nadal być powinna solidarność. Pod tym względem warto odwołać się

1 K. Waszczyńska, Wokółproblematyki tożsamości, „Rocznik Towarzystwa Naukowego Płockiego" (2014) nr 656, s. 48-73.

2 Z. Mach, Procesy rekonstrukcji tożsamości spotecznej w krajach Europy Środkowo-Wschodniej, „Nomos” (1994) nr 7/8, s. 10.

3 Por. J. Pollak, M. Mokre, Europäische Kulturpolitik als Identitätspolitik. Formen, Prozesse, Resultate, „Österreichische Zeitschrift für Politikwissenschaft” (1999) 3, s. 317-331. 
do etyki solidarności ks. Józefa Tischnera (1931-200o). W jego ujęciu solidarność - i ta widniejąca na sztandarach, i ta, kryjąca się w sercach stoczniowców, hutników, pielęgniarek, ludzi kultury, duchownych i naukowców - była jakby nowym cudem nad Wisłą, objawieniem ludzkiej godności, w szczególności zaś godności ludzkiej pracy ${ }^{4}$.

Jakkolwiek by było, solidarność - zdaniem Tischnera - jawi się przede wszystkim jako idea. Albowiem nie jest ona ani czystym pojęciem, ani gotową teorią etyczną - jest właśnie ideą. Pojęcia tym się zazwyczaj charakteryzują, że dają się stosunkowo łatwo zdefiniować, idee natomiast zawsze pozostają trochę niedookreślone. Są one raczej wzorami rzeczy niż wyrazem ich faktycznego stanu. Otóż solidarność jest czymś do odwzorowania. Nie wiąże się ona również z żadną gotową teorią. Teoria to jakiś system uzasadnień, w którym ,jedno trzyma się drugiego” i jedno drugie uzasadnia. Idea jest czymś, co w gruncie rzeczy nie potrzebuje uzasadnień; ona uzasadnia się sama przez się. Idea to jakby jakieś światło. Światło samo świeci, samo siebie „uzasadnia”. Idąc po cieniach, dochodzimy do światła. Każdy cień odsyła poza siebie, ale światło już dalej nie odsyła. Tego rodzaju światłem zdaje się być idea solidarności. Choć nie potrzebuje ona uzasadnień, to jednak - jak utrzymuje ks. Tischner - wymaga zrozumienia ${ }^{5}$.

Aby zrozumieć solidarność, należy uświadomić sobie, że człowiek jest zawsze solidarny z kimś i dla kogoś. Dzięki temu idea solidarności oświetla przestrzeń życia społecznego, politycznego, ekonomicznego. Prowadzi do etyki solidarności. W tym miejscu warto uwzględnić sobie intuicję etyki, do jakiej odwoływał się ks. Tischner w swoim myśleniu etycznym. Otóż jego zdaniem głównym zadaniem etyki jest pokazywanie człowiekowi, możliwie jednoznacznie, wśród jakich wartości biegnie jego los. Gdy człowiek zobaczy, jaki świat wartości go otacza, sam potrafi sformułować nakaz i zakaz, sam potrafi sobie poradzić, a gdy zajdzie potrzeba, potrafi również siebie ocenić. Do tego rodzaju wartości, kluczowych wartości, należy sumienie człowieka. Etyka solidarności chce być właśnie etyką sumienia. Zakłada ona, że człowiek jest istotą obdarzoną sumieniem. Sumienie to naturalny „zmysł etyczny” człowieka, w znacznym stopniu niezależny od

4 Por. Ł. Kobeszko, Solidarność. Dlaczego wg Tichnera była matym cudem nad Wista?, https:// pl.aleteia.org/2017/o6/28/lekcja-od-tischnera-warto-wierzyc-w-solidarnosc/(14.12.2019).

5 J. Tischner, Etyka solidarności oraz homo sovieticus, Wydawnictwo Znak, Kraków 2005, s. 16 . 
rozmaitych systemów etycznych. Mamy wiele systemów etycznych, ale sumienie jest jedno. Ono jest wcześniejsze niż owe systemy ${ }^{6}$.

Sumienie stanowi w człowieku rzeczywistość samodzielną, trochę jak rozum i wola. Człowiek może słuchać swego sumienia, zagłuszać je, może się go wyrzekać. Sumienie jest głosem, który woła wewnątrz człowieka. W tej perspektywie autentyczna solidarność jawi się jako solidarność sumień, jest solidarnością sumień. Sumienie jest fundamentem solidarności. Albowiem „być solidarnym” z człowiekiem, to zawsze móc liczyć na człowieka, a liczyć na człowieka, to - zdaniem Tischnera - wierzyć, że jest w nim coś stałego, co nie zawodzi. Sumienie jest w człowieku tym, co stałe i co nie sprawia zawodu. Musi być jednak spełniony najbardziej podstawowy warunek: trzeba mieć sumienie. Sumienia mają bowiem przede wszystkim ci, którzy chcą je mieć. Okazuje się, że człowiek może wyrzec się swojego sumienia, ma moc zniszczenia w sobie tego, co stanowi o jego człowieczeństwie, ale ma również moc odbudowania własnego sumienia ${ }^{7}$.

A oto jeszcze jedna myśl ks. Tischnera. Solidarność nie jest ideą abstrakcyjną. Bodźcem do jej powstania jest wołanie o pomoc człowieka, którego zranił drugi człowiek. Solidarność stanowi szczególne więzi międzyludzkie: człowiek wiąże się z drugim człowiekiem dla opieki nad tym, kto potrzebuje opieki. Wspólnota solidarności nie jest dla samej siebie, lecz dla pomocy człowiekowi, który został zraniony przez drugiego człowieka. Ksiądz Tischner, nawiązując do ewangelicznej przypowieści o miłosiernym Samarytaninie, wyjaśnia to tak: Najpierw jest ranny i jego krzyk. Potem odzywa się sumienie, które potrafi słyszeć i rozumieć ten krzyk. Dopiero stąd rośnie wspólnota, wspólnota solidarności ${ }^{8}$.

Czym jest solidarność? W przekonaniu ks. Tischnera jest ona „brater-

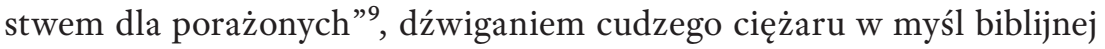
prawdy: "Jeden drugiego ciężary noście..." (Ga 6, 2). W tym spojrzeniu solidarność jest więc najbardziej fundamentalną postacią ludzkiego współdziałania, a jej paradygmatem jest postawa miłosiernego Samarytanina. Solidarność jest spontaniczna, nie potrzebuje zewnętrznego przeciwnika, lecz otwarta jest na wszystkich i nie zwraca się przeciwko komukolwiek,

6 J. Tischner, Etyka solidarności oraz homo sovieticus, dz. cyt., s. 17.

7 J. Tischner, Etyka solidarności oraz homo sovieticus, dz. cyt., s. 18.

8 J. Tischner, Etyka solidarności oraz homo sovieticus, dz. cyt., s. 18-2o.

9 J. Tischner, Etyka solidarności oraz homo sovieticus, dz. cyt., s. 20. 
aby go zranić ${ }^{10}$. Jej fundamentem jest nie tylko sumienie, ale także ludzka godność i prawda ${ }^{11}$.

W Polsce owa wspólnota solidarności przybrała niegdyś ogromne, imponujące rozmiary. Zapoczątkowała ruch, który stanowił krzyk ludzi zranionych przez nieludzki system; ruch, który potrafił słyszeć i rozumieć ten krzyk, domagając się respektowania podstawowych praw człowieka i zasad sprawiedliwości. Jednakże czynił to w sposób pokojowy, bez żądzy odwetu, zemsty i rewanżu. Wzywał nie do wdeptania w ziemię tych, którzy zadawali rany, ale do spotkania z nimi, do dialogu w prawdzie, która wyzwala (por. J 8, 32). U podstaw tego rodzaju rozumienia solidarności leży przekonanie o uniwersalnej sile solidarności, która staje się jakby nowym imieniem miłości społecznej, a więc wartości na wskroś ewangelicznej. W tej perspektywie etycznej nie można rezygnować, nie wolno rezygnować z prób spotkania z drugim człowiekiem, by opatrzyć jego rany albo wspólnie z nim, budząc jego sumienie, uleczyć rany, które zadał on innym ludziom ${ }^{12}$.

Idea solidarności związana jest w sposób szczególny z rzeczywistością ludzkiej pracy. Ksiądz Tischner postrzegał solidarność jako uwolnienie pracy od bezsensu i zbędnego „bólu” pochodzącego od drugiego człowieka. Z ludzkiego doświadczenia wiadomo, że praca musi wiązać się nieuchronnie z pewnym właściwym jej „bólem”, ale „ból” pochodzący z „moralnego wyzysku” jest bólem zbędnym i możliwym do usunięcia ${ }^{13}$.

Warto jednak postawić pytanie bardziej podstawowe, a mianowicie: jak ks. Tischner rozumiał pracę? Praca - w jego rozumieniu - jest szczególną formą rozmowy człowieka z człowiekiem, służącą podtrzymywaniu i rozwojowi ludzkiego życia. W swym najbardziej podstawowym wymiarze praca jest działaniem służącym życiu, jest siłą zdolną przekształcać tworzywo w produkt. Jednak to działanie przeniknięte jest poznaniem i myślą. Dlatego Tischner, zainspirowany Norwidem, określa pracę także

10 Por. Ł. Kobeszko, Solidarność. Dlaczego wg Tichnera była matym cudem nad Wistą?, https:// pl.aleteia.org/2017/o6/28/lekcja-od-tischnera-warto-wierzyc-w-solidarnosc/ (25.12.2019).

11 Por. J. Tischner, Etyka solidarności oraz homo sovieticus, dz. cyt., s. 12-14.

12 Por. M. Pyka, Pomiędzy „homo sovieticus” a „homo aemulans”. Uwagi o idei solidarności i potrzebie filozofii pracy w społeczeństwie rynkowym, „Warszawskie Studia Teologiczne” 22 (2009), s. 112-114.

13 J. Tischner, Etyka solidarności oraz homo sovieticus, dz. cyt., s. 33. 
jako „czynne myślenie”"14. W jej obrębie jest miejsce na prawdę zarówno w sensie podmiotowym (dotyczącym stosunków między ludźmi pracującymi), jak i przedmiotowym (dotyczącym techniki) ${ }^{15}$.

Ujmując pracę $\mathrm{w}$ aspekcie etycznym, ks. Tischner sformułował diagnozę sytuacji, w jakiej praca może się znajdować. Odnosząc się do realiów czasu, w jakim dokonywał namysłu nad etosem solidarności, diagnozował sytuację jako „chorobę” polskiej pracy, wskazywał na „moralny wyzysk” oraz głosił potrzebę „pracy nad pracą” (chodzi o refleksję nad kulturą pracy) ${ }^{16}$.

Etos solidarności każe upomnieć się o sens i godność ludzkiej pracy, a w konsekwencji o godność człowieka, który pracuje. Godność człowieka pracującego wyraża się w trzech najbardziej elementarnych prawach:

- prawie do „najwyższej Nadziei, która wiąże człowieka i wspólnoty

ludzkie z Bogiem";

- prawie do pracy z sensem;

- prawie do tworzenia zrzeszeń ludzi pracy ${ }^{17}$.

Konkludując znaczenie godności człowieka pracy, Tischner uznaje tę godność za formę niepodległości człowieka. Więcej, wyraża przekonanie, że niepodległa godność ludzi pracy jest dziś niepodległością Polski ${ }^{18}$.

\section{Solidarność w myśli Jana Pawła II}

Ideę solidarności krzewił nie tylko ks. Józef Tischner. Jego myśl trzeba wszakże postrzegać głównie w kontekście encykliki św. Jana Pawła II Laborem exercens. Papież bowiem niestrudzenie nauczał o solidarności a nade wszystko zachęcał do postawy solidarności. Dzięki temu myśl św. Jana Pawła II przenikała wielki ruch społeczny, jaki zrodził się w Polsce w latach 8o. xx stulecia. Jak wiadomo, ruch ten przyjął nazwę „Solidarność".

14 Cyt. za: M. Pyka, Pomiędzy „,homo sovieticus” a „homo aemulans”..., dz. cyt., s. 107.

15 J. Tischner, Etyka solidarności oraz homo sovieticus, dz. cyt., s. 25-29.

16 J. Tischner, Etyka solidarności oraz homo sovieticus, dz. cyt., s. 30-33 i 124.

17 J. Tischner, Etyka solidarności oraz homo sovieticus, dz. cyt., s. 113; por. M. Pyka, Pomiędzy "homo sovieticus" a „homo aemulans"..., dz. cyt., s. 106.

18 Por. J. Tischner, Etyka solidarności oraz homo sovieticus, dz. cyt., s. 114-116. 
Papież w swoim nauczaniu akcentuje najbardziej podstawowe prawdy, które jakby definiują potrzebę solidarności ludzi pracy, stanowią o tożsamości ich ruchu. Oto najważniejsze z nich: podmiotem pracy jest człowiek pracujący - osoba ludzka ${ }^{19}$; „to praca jest dla człowieka a nie człowiek dla pracy"20; ostatecznym celem pracy jest człowiek, a nie pomnażanie kapi$\mathrm{tału}^{21}$; społeczna rola pracy polega nie tylko na zaspokajaniu naturalnych potrzeb ludzkich, ale również na tym, że jest ona czynnikiem tworzącym więź społeczną, jest rodzajem „porozumienia” człowieka z człowiekiem ${ }^{22}$; praca jest „siłą społeczną”, „siłą budowania wspólnoty”23.

W tym miejscu warto przytoczyć myśl encykliki na temat godności pracy. Otóż praca - wedle Jana Pawła II - jest dobrem człowieka - dobrem jego człowieczeństwa. I to nie dobrem tylko „użytecznym” czy „użytkowym”, ale dobrem „godziwym”, czyli odpowiadającym godności człowieka, wyrażającym tę godność i pomnażającym ją. Przez pracę człowiek nie tylko przekształca przyrodę, dostosowując ją do swoich potrzeb, ale także urzeczywistnia siebie jako człowiek, a także poniekąd bardziej „staje się człowiekiem" ${ }^{24}$.

Otóż wszędzie tam, gdzie zagrożona jest godność pracy ludzkiej (de facto podmiotu pracy i jego egzystencji), niezbędna jest solidarność. Zdaniem Jana Pawła Ir jej potrzeba podyktowana jest racją sprawiedliwości społecznej. W tym kontekście dostrzega on powstanie frontów solidarności jako swoistych znaków czasu. W encyklice Laborem exercens widnieją bowiem słowa: „Owe fronty solidarności w dziedzinie pracy ludzkiej - solidarności, która nie może być zamknięta na dialog i na współpracę z innymi mogą być potrzebne również w takich warunkach i wśród takich warstw społecznych, które dawniej nie były nimi objęte, a w zmieniających się układach społecznych oraz warunkach życia doznają faktycznej «proletaryzacji» lub już wręcz się znajdują w stanie «proletariatu» [...]. Dla realizacji sprawiedliwości społecznej w różnych częściach świata, w różnych krajach i we wzajemnych pomiędzy nimi stosunkach, potrzebne są coraz

19 Ewangelia pracy. Encyklika Jana Pawta II «Laborem exercens» wraz z komentarzem, red.

J. Chmiel i S. Ryłko, Kraków 1983, 6, s. 20 (dalej: LE).

20 LE 6, s. 22.

21 LE 7, s. 23.

22 LE 12-13, s. 33-38.

23 LE 2O, s. 53-54.

24 LE 9, s. $27-28$. 
to nowe fronty solidarności ludzi pracy, a także solidarności z ludźmi pracy. Solidarność taka winna występować stale tam, gdzie domaga się tego społeczna degradacja podmiotu pracy, wyzysk pracujących i rosnące obszary nędzy, a nawet wręcz głodu. [Dziś] «ubodzy» pojawiają się pod różnymi postaciami, pojawiają się w różnych miejscach i w różnych momentach, pojawiają się w wielu wypadkach jako wyniknaruszenia godności ludzkiej pracy, bądź przez to, że zostają ograniczone możliwości pracy ludzkiej, a więc przez klęskę bezrobocia, bądź przez to, że się zaniża wartość pracy i prawa, jakie z niej wynikają, w szczególności prawo do sprawiedliwej płacy, do zabezpieczenia osoby pracownika oraz rodziny"25.

Jan Paweł II uczynił solidarność jednym z ważnych tematów, do którego nieustannie powracał w swoim nauczaniu moralnym i społecznym. Uczynił to nie tylko w encyklice Laborem exercens, ale także w pozostałych encyklikach społecznych: Sollicitudo rei socialis ${ }^{26}$ z 30 grudnia 1987 roku i Centesimus annus ${ }^{27} \mathrm{Z} 1$ maja 1991 roku.

\section{Próba konkluzji}

Powraca zatem pytanie o tożsamość ideową solidarności. Jak już wspomniano, tożsamość ideowa w obszarze życia społecznego w znacznym a być może nawet w decydującym - stopniu definiowana jest przez cele polityczne. Albowiem świadomość polityki rozumianej jako roztropna realizacja dobra wspólnego stanowi istotny, choć z pewnością nie jedyny, punkt oparcia dla tożsamości ideowej. Tej świadomości nie zabrakło ludziom polskiego świata pracy w latach 80 . minionego wieku. Nie zabrakło jej stoczniowcom, górnikom, hutnikom, pracownikom tysięcy zakładów w całej Polsce, ale także w wielkim ruchu solidarności ową świadomość przejawili ludzie nauki i kultury czy szeroko pojęte elity społeczne i intelektualne.

25 LE 8, s. 25-26.

26 Encyklika «Sollicitudo rei socialis» Ojca Świętego Jana Pawta II z okazji dwudziestej rocznicy ogłoszenia «Populorum progressio», Libreria Editrice Vaticana, Watykan 1988, 33, s. 63; 38, s. 73; 39, s. 74-76; 40, s. 77-79.

27 Encyklika «Centesimus annus» Ojca Świętego Jana Pawła II w setną rocznicę encykliki «Rerumnovarum», Wydawnictwo Duszpasterstwa Rolników, Włocławek 1991, 22-29, s. 32-42. 
Wydaje się, że tożsamość ideowa polskiej solidarności była - i chyba nadal jest - postrzegana przede wszystkim jako afirmacja etosu ludzkiej pracy, a zwłaszcza godności człowieka pracy. Nie jest dziełem przypad$\mathrm{ku}$, że refleksji na temat podmiotowego wymiaru pracy tak wiele uwagi poświęcili duchowi przywódcy ruchu solidarności - papież Jan Paweł II czy ks. Józef Tischner. W tym kontekście nie sposób nie zauważyć, że historia w wystarczającym stopniu zweryfikowała słynną papieską tezę zawartą w encyklice Laborem exercens: „Praca ludzka stanowi klucz, i to chyba najistotniejszy klucz, do całej kwestii społecznej, jeżeli staramy się ją widzieć naprawdę pod kątem dobra człowieka"28. Wielki ruch solidarności w Polsce, o ile chce być wierny deklarowanym przez siebie ideałom, nie może więc utracić swojej tożsamości, jaką jest - co warto raz jeszcze podkreślić - ludzka praca i jej etos, a szczególnie jej godność.

\section{Abstrakt}

\section{Uwagi o tożsamości ideowej polskiego ruchu społecznego „Solidarnośc”}

Pytanie o tożsamość ideową polskiego ruchu społecznego „Solidarność” jest głównym przedmiotem niniejszego tekstu. Przyjmuje się robocze założenie, że tożsamość ideową jako taką można definiować za pomocą celów politycznych, obejmując niejako wspólne wartości, tradycje i oczekiwania względem przyszłości. Tożsamość ideową wprowadza w czyny, realizuje właśnie tożsamość polityczną.

W oparciu o sens, jaki kryje w sobie kategoria tożsamości, można bardziej zrozumieć to, czym była i czym nadal być powinna solidarność. Prezentowane rozważania nawiązują do etyki solidarności ks. Józefa Tischnera (1931-2000) i encyklik społecznych papieża Jana Pawła II. W konkluzji zawarte jest stwierdzenie, że tożsamość ideowa „Solidarności” była - i chyba nadal jest - postrzegana przede wszystkim jako afirmacja etosu ludzkiej pracy. W szczególności chodzi o poszanowanie godności człowieka pracy. Obrona tej tożsamości jest jednocześnie wciąż aktualnym wyzwaniem dla polskiego ruchu, któremu na imię „Solidarność”.

28 LE 3, s. 15. 
Słowa kluczowe: tożsamość ideowa, idea solidarności, etyka solidarności, encyklika „Laborem exercens”, godność pracy ludzkiej, Jan Paweł II, Józef Tischner

\section{Abstract}

Comments on ideological identity of the Polish social movement „Solidarity”

The question about the ideological identity of the Polish social movement "Solidarity" is the main subject of this text. It is assumed that the ideological identity as such can be defined by means of political goals, embracing common values, traditions and expectations for the future. He introduces ideological identity into deeds, realizes just political identity.

Based on the sense in the category of identity, you can understand more what solidarity was and should continue to be. The considerations presented refer to the ethics of solidarity, Fr. Józef Tischner (1931-200o) and the social encyclical of Pope John Paul II.

The conclusion states that the ideological identity of „Solidarity” was and probably still is seen primarily as an affirmation of the ethos of human work. In particular, it is about respecting the dignity of a working man. Defending this identity is also still a current challenge for the Polish movement, whose name is „Solidarity”.

Keywords: ideological identity, idea of solidarity, ethics of solidarity, encyclical „Laborem exercens”, dignity of human work, John Paul II, Józef Tischner

\section{Bibliografia}

Encyklika «Centesimus annus» Ojca Świętego Jana Pawła II w setna rocznicę encykliki «Rerum novarum», Wydawnictwo Duszpasterstwa Rolników, Włocławek 1991. 
Encyklika «Sollicitudo rei socialis» Ojca Świętego Jana Pawła II z okazji dwudziestej rocznicy ogłoszenia «Populorum progressio», Libreria Editrice Vaticana, Watykan 1988.

Ewangelia pracy. Encyklika Jana Pawta II «Laborem exercens» wraz z komentarzem, red. J. Chmiel i S. Ryłko, Polskie Towarzystwo Teologiczne, Kraków 1983.

Kobeszko Ł., Solidarność. Dlaczego wg Tichnera była małym cudem nad Wista?, https://pl.aleteia.org/2017/o6/28/lekcja-od-tischnera-warto-wierzyc-w-solidarnosc/ (14.12.2019).

Mach Z., Procesy rekonstrukcji tożsamości społecznej w krajach Europy Środkowo-Wschodniej, „Nomos” (1994) nr 7/8, s. 9-23.

Pollak J., Mokre M., Europäische Kulturpolitik als Identitätspolitik. Formen, Prozesse, Resultate, „Österreichische Zeitschrift für Politikwissenschaft” (1999) 3, s. 317-331.

Pyka M., Pomiędzy „homo sovieticus” a „homo aemulans”. Uwagi o idei solidarności i potrzebie filozofii pracy w społeczeństwie rynkowym, „Warszawskie Studia Teologiczne" 22 (2009), s. 103-114.

Tischner J., Etyka solidarności oraz homo sovieticus, Wydawnictwo Znak, Kraków 2005.

Waszczyńska K., Wokót problematyki tożsamości, „Rocznik Towarzystwa Naukowego Płockiego" (2014) nr 656, s. 48-73. 